\title{
Immunological Detection of Heterogeneous O-antigen Containing Lipopolysaccharides in Escherichia coli
}

\author{
By LOEK VAN ALPHEN, * FRANSJE VAN KEMPEN-DE TROYE \\ AND H. C. ZANEN \\ Laboratorium voor de Gezondheidsleer, University of Amsterdam, Mauritskade 57, \\ NL-1092 AD Amsterdam, The Netherlands
}

(Received 14 April 1982; revised 15 May 1982)

\begin{abstract}
The components of the cell envelopes of Escherichia coli $\mathrm{O} 1: \mathrm{K} 1, \mathrm{O} 7: \mathrm{K} 1, \mathrm{O} 18: \mathrm{K} 1$ and $\mathrm{O} 83: \mathrm{K} 1$ strains were separated on SDS-polyacrylamide gels. Longitudinal slices $(50 \mu \mathrm{m}$ thick) of the gel were incubated with typing sera for $E$. coli $\mathrm{O} 1, \mathrm{O} 7, \mathrm{O} 18$ and 083 , followed by detection of the bound antibodies with ${ }^{125} \mathrm{I}$-labelled protein $\mathrm{A}$ and autoradiography. The antisera reacted with many cell envelope components of strains both with the homologous O-serotype and heterologous O-serotypes. With O-typing sera cross-reactions with heterologous cells and cells boiled for $2 \mathrm{~h}$ were found. Up to 40 serotype-specific bands at regular positions with molecular weights between 12000 and 100000 were demonstrated. Since these bands were also observed when purified lipopolysaccharide and unabsorbed homologous O-typing sera were used, it was concluded that these bands represented lipopolysaccharide molecules with increasing molecular weight, all of which contained $\mathrm{O}$-antigen specific immunodeterminants. The band patterns were not influenced by the growth conditions of the cells or the various isolation procedures for the cell envelopes. Comparison of various strains serotyped as $\mathrm{O} 18$ revealed strain differences with respect to their lipopolysaccharide band patterns. In the case of $\mathrm{O} 21$ - and 083 -serotyped strains lipopolysaccharide cross-reactions, which were detected by agglutination, were analysed in detail using the gel immunoradioassay method. These cross-reactions appeared to be caused by the presence of common determinants on their lipopolysaccharides and polysaccharide-like material. The cross-reacting antibodies could be removed by cross-absorption. It is concluded that the immunological detection of lipopolysaccharides and other components of $E$. coli in gels is an important tool in (1) the control of the specificity of typing antisera, (2) the study of the nature of cross-reacting antigens and (3) the study of the nature and uniformity of the various $\mathrm{O}$ and $\mathrm{K}$-serotypes.
\end{abstract}

\section{INTRODUCTION}

The outer membrane of Gram-negative bacteria contains protein, phospholipid and lipopolysaccharide. Lipopolysaccharide is exclusively located in the outer monolayer of the outer membrane, directing its sugar chains into the medium (Mühlradt \& Golecki, 1975). It is an important component for the structure and function of the outer membrane (Alphen et al., 1976; Burnell et al., 1980; Osborn, 1979).

Lipopolysaccharide molecules are composed of a lipid A part, carrying fatty acids necessary for the embedding of lipopolysaccharide in the membrane, and of a sugar chain which is hydrophilic. In many strains from natural sources this sugar chain contains the O-antigen in addition to the core part (Galanos et al., 1977). Enterobacteriaceae containing lipopolysaccharide with $\mathrm{O}$-antigen demonstrate a smooth colony morphology. In contrast, colonies of bacteria lacking this part of the lipopolysaccharide molecule have a rough appearance. The $\mathrm{O}$-antigen is strongly immunogenic and forms the basis of serological typing schemes. For Escherichia coli, $164 \mathrm{O}$-serotypes have been described (Ørskov et al., 1977), indicating that the composition of the 
O-antigen is widely variable in nature. The structures of the core and lipid A part of lipopolysaccharide are much more conserved (Galanos et al., 1977).

Heterogeneity in the molecular size of lipopolysaccharide within a strain has frequently been observed, but only recently has detailed information become available from the analysis of radiolabelled lipopolysaccharide in SDS-polyacrylamide gels. Escherichia coli O111 (Galanos et al., 1977), Salmonella typhimurium LT2 (Goldman \& Leive, 1980; Palva \& Mäkelä, 1980) and Chromatium vinosum (Hurlbert \& Hurlbert, 1977) lipopolysaccharides consist of at least 40 different molecular species with increasing numbers of repeating $\mathrm{O}$-antigen subunits (Goldman \& Leive, 1980). Molecules with short or long side chains are predominant. The length distribution of the lipopolysaccharide molecules is probably caused by transfer of incomplete $\mathrm{O}$ antigen from the polyisoprenoid intermediate to the core-lipid A backbone during the biosynthesis of lipopolysaccharide (Goldman \& Leive, 1980; Robbins \& Wright, 1971).

In this paper we describe the heterogeneity of lipopolysaccharides from several invasive $E$. coli strains which were isolated from neonates with meningitis and from standard strains which are in use for O-serotyping of $E$. coli. Analysis of lipopolysaccharides was performed immunochemically on slices of SDS-polyacrylamide gels with antisera specific for lipopolysaccharide (Poolman, et al., 1978; Poolman \& Zanen, 1980). The implications of these results for Oserotyping are discussed.

\section{METHODS}

Strains and growth conditions. Escherichia coli was isolated from the cerebrospinal fluid or blood from neonates with meningitis living in The Netherlands. Most of these strains are encapsulated (K1-serotype); OK-serotypes were determined at the Rijks Instituut voor de Volksgezondheid, Bilthoven, The Netherlands. The reference strains E. coli $083: \mathrm{K}^{-}, \mathrm{O} 21: \mathrm{K}^{-}, \mathrm{O} 7: \mathrm{K}^{-}, 021: \mathrm{K} 20$, O18:K76 and O4:K3 were obtained from Dr P. A. M. Guinée, Rijks Instituut voor de Volksgezondheid, Bilthoven, The Netherlands. Escherichia coli K12 strain PC1349 (Phabagen Collection, from Miss H. S. Felix, Padualaan 8, Utrecht) was used as a rough non-pathogenic strain. Cells were grown overnight in Brain Heart Infusion broth (Difco) at $37^{\circ} \mathrm{C}$ under aeration unless otherwise indicated.

Isolation and characterization of cell envelopes. The procedure for the isolation of cell envelopes described by Lugtenberg et al. (1975) was followed. Cells were harvested by centrifugation (10 min at $10000 \mathrm{~g}$ ) washed with $0.9 \%(\mathrm{w} / \mathrm{v}) \mathrm{NaCl}$ and disrupted by ultrasonic treatment in $50 \mathrm{~mm}$-Tris/ $\mathrm{HCl} \mathrm{pH} 8.0$ using a Branson sonifier at $70 \mathrm{~W}$. In some experiments cells were either disrupted with a French pressure cell (Burnell et al., 1980) or by osmotic lysis (Heerikhuisen et al., 1975). Whole cells were removed from the lysate by low speed centrifugation $(20 \mathrm{~min}$ at $3000 \mathrm{~g})$ and the cell envelopes obtained from the supernatant by ultracentrifugation (45 min at $225000 \mathrm{~g}$ ). The cell envelopes were washed once with $2 \mathrm{~mm}$-Tris $/ \mathrm{HCl} \mathrm{pH} 7.8$ and the ultracentrifugation step was repeated. The pellet was solubilized in mixture containing $62.5 \mathrm{mM}$-Tris $/ \mathrm{HCl}, 2 \%(\mathrm{w} / \mathrm{v}) \mathrm{SDS}, 10 \%(\mathrm{v} / \mathrm{v}) \mathrm{glycerol}$, $5 \%(\mathrm{v} / \mathrm{v}) 2$-mercaptoethanol and $0.001 \%(\mathrm{w} / \mathrm{v})$ bromophenol blue, $\mathrm{pH} 6.8$; after boiling for $5 \mathrm{~min}$ the solution was applied to $11 \%(\mathrm{w} / \mathrm{v})$ SDS-polyacrylamide gels (Lugtenberg et al., 1975) in a slab gel apparatus (Pharmacia). Proteins were stained with Coomassie brilliant blue (Fairbanks et al., 1971) and (lipo)polysaccharides by employing periodic acid-Schiff staining (Segrest \& Jackson, 1972).

For the immunological detection of lipopolysaccharides, unstained gels were sliced longitudinally into $50 \mu \mathrm{m}$ slices at $-30^{\circ} \mathrm{C}$ in a Bright 5030 cryostat microtome. Slices were incubated with type-specific antisera and bound antibodies were visualized by (1) incubation with goat anti-rabbit IgG-peroxidase followed by enzymic staining with 3-amino-9-ethylcarbazole [the SDS-gel immunoperoxidase technique (SGIP; Poolman et al., 1978)] or (2) by incubation with ${ }^{125} \mathrm{I}$-labelled protein $\mathrm{A}$, followed by autoradiography [the gel immunoradioassay technique (GIRA; Poolman \& Zanen, 1980)].

Antisera and O-agglutination. Antisera for typing of $\mathrm{O} 1,07,018,021$ and 083 lipopolysaccharides were obtained from the $E$. coli typing centres in The Netherlands (Rijks Instituut voor de Volksgezondheid) and in Denmark (International E. coli and Klebsiella Center, Copenhagen). OK-sera and O-sera were raised in rabbits against cells of strains 790163I (O83:K1), $780401 \mathrm{I}$ and 780699 (O18:K1), 800014 (O7:K1), 770706 (O1:K1) and $781123(\mathrm{O} 21: \mathrm{K} 1)$ as described (Ørskov et al., 1977). Sera were absorbed with equal amounts of fresh and boiled $(2 \mathrm{~h})$ cells of strains with an O-serotype different from that of the homologous strain. Strain O4:K 3 was used for absorption of O1- and O7-antiserum; similarly strains O4:K3 and 790163I (O83:K1) were used to absorb O18antiserum, and strains $\mathrm{O} 4: \mathrm{K} 3$ and $780401 \mathrm{I}(\mathrm{O} 18: \mathrm{K} 1)$ for O83-antiserum. Boiled cells were washed twice with 10 mM-sodium phosphate/ $0 \cdot 1 \mathrm{M}-\mathrm{NaCl}$ buffer $\mathrm{pH} 7 \cdot 4$. For absorption, packed cells were suspended in serum in a $1: 1$ $(\mathrm{v} / \mathrm{v})$ ratio. Serum was recovered from the incubation mixture as the supernatant obtained after ultracentrifugation $(30 \mathrm{~min}$ at $100000 \mathrm{~g}$ ). The specificity of the antisera was analysed by means of the SGIP and/or GIRA 
techniques using cell envelopes of $E$. coli $\mathrm{O} 1: \mathrm{K} 1,07: \mathrm{K} 1,018: \mathrm{K} 1$ and $083: \mathrm{K} 1$ strains as antigens. This treatment was apparently sufficient to remove most of the cross-reacting antibodies. In some cases additional absorptions were required with cells (fresh or boiled) or with lysates of cells obtained by ultrasonic treatment (Lugtenberg et al., 1975) in order to remove particular protein reactions.

Agglutination was performed in V-shaped microtitre trays with serial dilutions of anti-O sera, using cells boiled for $2 \mathrm{~h}$ as antigen. The results were read after incubation for $16 \mathrm{~h}$ at $50^{\circ} \mathrm{C}$ (Ørskov et al., 1977).

Isolation of lipopolysaccharide. Lipopolysaccharide was isolated from cell envelopes by use of the phenol/water method (Westphal \& Jann, 1965) as modified by Lindberg \& Holme (1972). The isolated lipopolysaccharide contained less than $1 \%$ protein based on protein staining of an SDS-polyacrylamide gel loaded with $100 \mu \mathrm{g}$ lipopolysaccharide. It was negative in the coagglutination test for $\mathrm{K} 1$ polysaccharide at a concentration of $10 \mathrm{mg}$ $\mathrm{ml}^{-1}$ and contained less than $1 \%$ nucleic acid, based on measurements of the absorbance at 254 and $280 \mathrm{~nm}$.

\section{RESULTS}

\section{Immunological detection of $01,07,018$ and 083 lipopolysaccharide in SDS gels}

Escherichia coli strains with serotypes $\mathrm{O} 1, \mathrm{O} 7, \mathrm{O} 18$ and $\mathrm{O} 83$ are frequently isolated from patients with neonatal meningitis in The Netherlands (Alphen et al., 1982). Four representative strains from our collection were chosen for this study. The protein pattern of the cell envelopes of these four strains is shown in Fig. 1a. Periodic Schiff staining of SDS gels resulted in a colour reaction at the front of the gel (Fig. $1 b$ ), where rough lipopolysaccharide is expected (Goldman \& Leive, 1980). Longitudinal slices of the gel were incubated with antisera prepared for O-serotyping by agglutination. The results of the analysis with anti-O83, anti-O18, anti-O7 and anti-O1 sera followed by subsequent incubation with ${ }^{125} \mathrm{I}$-labelled protein $\mathrm{A}$ and autoradiography are shown in Fig. $1 c, d, e$ and $f$, respectively. Many cell envelope components were recognized by the antisera and extensive cross-reactions were observed with strains belonging to heterologous serotypes. This phenomenon appeared to be general for many agglutinating typing antisera which are used for $\mathrm{O}$ (and $\mathrm{K}$ ) serotyping. Further absorption of anti-O1, anti-O7, anti-O18 and anti-O83 sera rendered them monospecific for the homologous strains as tested by GIRA. This coincided with a two to fourfold reduction in O-agglutination titres, mainly due to the disappearance of cross-reacting antibodies against cell envelope proteins and rough lipopolysaccharide. The GIRA results observed for the absorbed anti-O83, anti-O18, anti-O7 and anti-O1 sera are shown in Fig. $1 g, h, i$ and $j$, respectively. Repeating band patterns were observed in the cell envelopes of the homologous strains. These bands have apparent molecular weights from about 12000 up to 100000 as assessed by the use of protein markers. The various serotypes were associated with different patterns; the distances between the bands and the relative intensities of the bands varied by serotype. However, most bands were found in the low (10000-25000) and high (40000-80000) molecular weight regions.

Since O-serotyping depends on determinants on lipopolysaccharide molecules we supposed that the bands probably represent a set of lipopolysaccharide molecules, each of which carries serotype-specific immunodeterminants. Therefore, the nature of the bands was further investigated by analysing purified lipopolysaccharide immunochemically. The results for $\mathrm{O} 83$ lipopolysaccharide are summarized in Fig. 2. A band pattern identical to the pattern obtained with cell envelopes was observed with purified lipopolysaccharide using specific anti-O83 serum (lanes 4 and 5). Moreover the same pattern was seen with crude OK-serum which contained antibodies against lipopolysaccharide and many outer membrane proteins. Similar results were obtained for $\mathrm{O} 1, \mathrm{O} 7$ and $\mathrm{O} 18$ lipopolysaccharide and the corresponding antisera. In addition, various antisera obtained from different rabbits gave identical results for each of these lipopolysaccharides. The results obtained using the GIRA technique agreed with those obtained with SGIP analyses.

The influence on the band pattern of various cell growth conditions and different procedures for the isolation of cell envelopes was analysed for $\mathrm{O} 83$ and 018 lipopolysaccharides. Escherichia coli $\mathrm{O} 83: \mathrm{K} 1$ strain $790163 \mathrm{I}$ and $\mathrm{O} 18: \mathrm{K} 1$ strain $780401 \mathrm{I}$ was harvested at (1) stationary phase ( $16 \mathrm{~h}$ after growth at $22^{\circ} \mathrm{C}$ without shaking), (2) late-exponential phase $\left(A_{660}=0.9\right.$; after growth at $37^{\circ} \mathrm{C}$ with vigorous agitation), and (3) stationary phase $\left(16 \mathrm{~h}\right.$ after growth at $37^{\circ} \mathrm{C}$ with vigorous agitation). These variations did not result in differences in the band patterns of the 
(a)

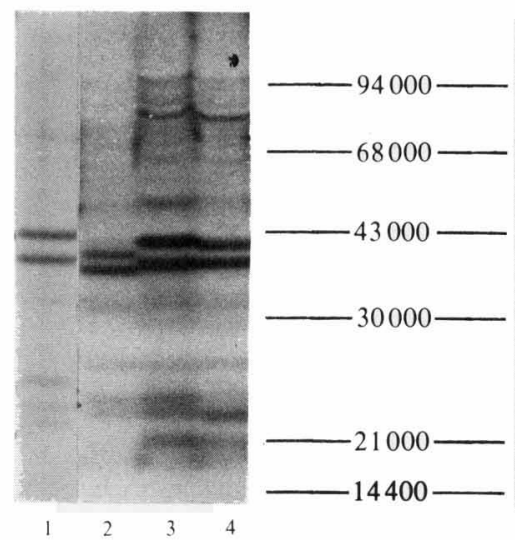

(c)

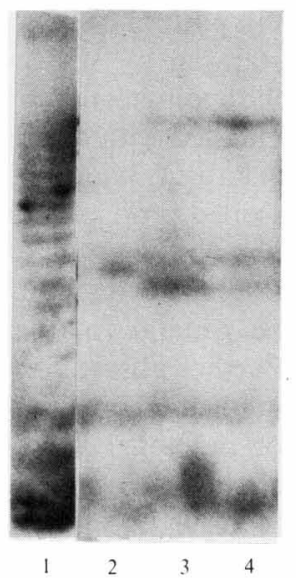

(g)

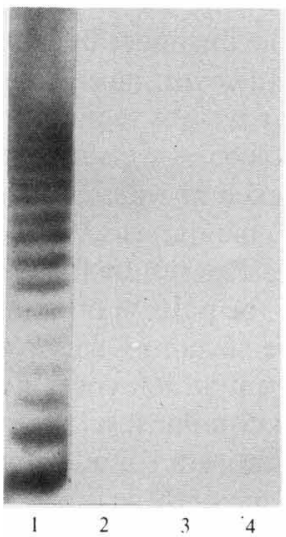

(d)

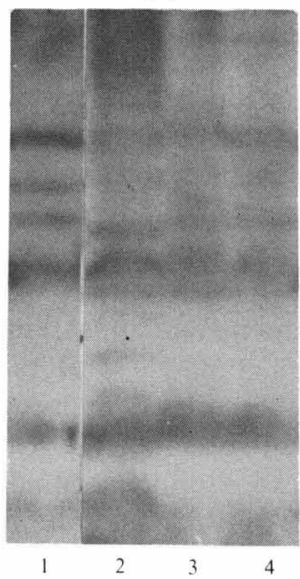

(h)

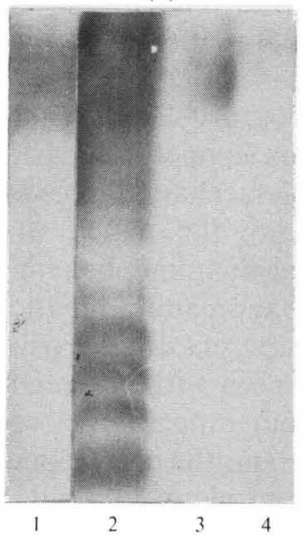

(b)

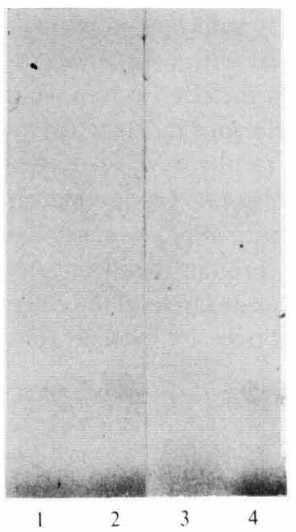

(e)

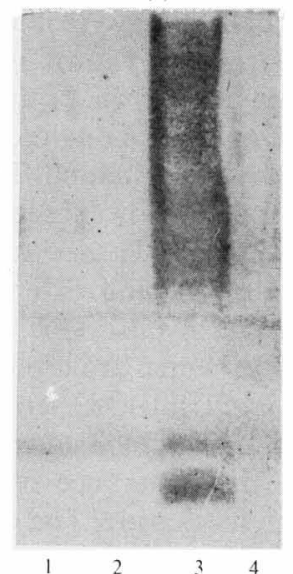

(i)

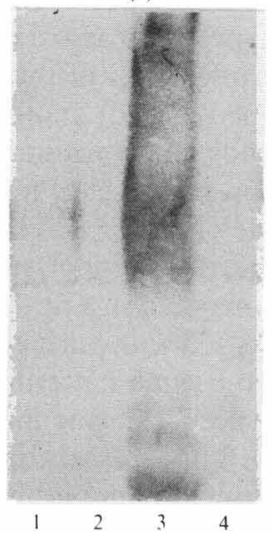

$(f)$

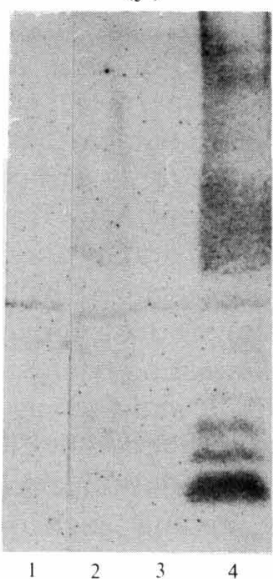

(j)

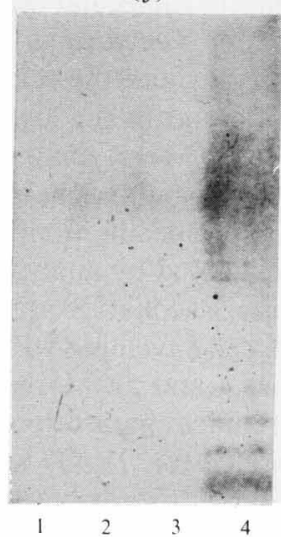

Fig. 1. Immunodetection of O1, O7, O18 and O83 lipopolysaccharides in slices of SDS-polyacrylamide gels. A gel with cell envelopes of representative $E$. coli strains from patients with meningitis was sliced and the slices were incubated with O-typing antisera. In each case cell envelopes were obtained from: lane 1, strain 790163I (O83:K1); lane 2, strain 780401I (O18:K1); lane 3, strain $780755(\mathrm{O} 7: \mathrm{K} 1)$; lane 4 , strain $770706(\mathrm{O} 1: \mathrm{K} 1)$. The reactions between antibodies and antigens were visualized by autoradiography after incubating with ${ }^{125} \mathrm{I}$-labelled protein A. (a) Polypeptide pattern shown by Coomassie brilliant blue staining, $(b)$ periodic Schiff staining. $(c-j)$ Autoradiograms obtained after incubation with the following typing sera: $(c)$ anti-O83, $(d)$ anti-O18, $(e)$ anti-O7, $(f)$ anti-O1, $(g)$ absorbed anti-O83, $(h)$ absorbed anti-O18, $(i)$ absorbed anti-O7, $(j)$ absorbed anti-O1. The positions of molecular weight marker bands are indicated. 


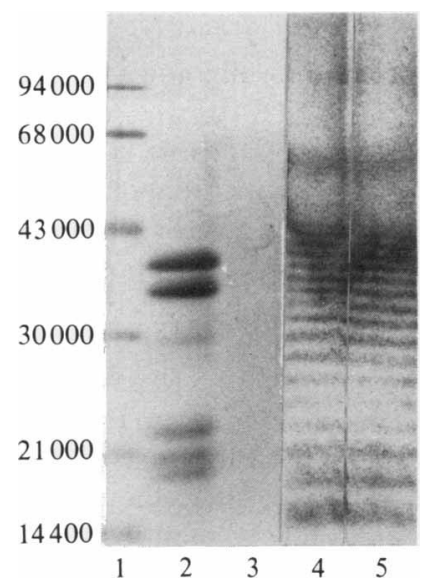

Fig. 2. Analysis of the molecular nature of 083 band patterns. Lane 1, molecular weight markers; lane 2, protein staining of cell envelopes of strain $790163 \mathrm{I}(\mathrm{O} 83: \mathrm{K} 1)$; lane 3, protein staining of lipopolysaccharide isolated from strain 790163I (O83:K1); lane 4, GIRA pattern of cell envelopes and lane 5, GIRA pattern of isolated lipopolysaccharide of strain 790163I (O83:K1), both with specific O83 antiserum.

cell envelopes after reaction with specific $\mathrm{O} 18$ and 083 antisera. Moreover, the band patterns were not dependent on the way in which the cell envelopes were isolated. The bands were also observed when intact cells were applied to the gel, although the results were difficult to interpret because of the relatively low amount of lipopolysaccharide which is present in whole cell lysates.

\section{Strain specificity}

Several reference O18-serotype strains were analysed with anti-O18 serum by GIRA. The results for five such strains are shown in Fig. 3. In cell envelopes of four out of five strains (lanes $1,3,4$ and 5) band patterns became visible after incubation with anti-O18 serum. The differences observed in the relative positions of the bands in the gel slices could not be ascribed to changes in the lipopolysaccharides resulting from storage (Goldman \& Leive 1980) since only freshly isolated material was used. Since strain H882-79 still agglutinated with anti-O18 serum in high titres and showed a polysaccharide-like reaction (Poolman et al., 1978) at the top of the gel (lane 2), the results indicate that the 018 serotype is heterogeneous.

(a)

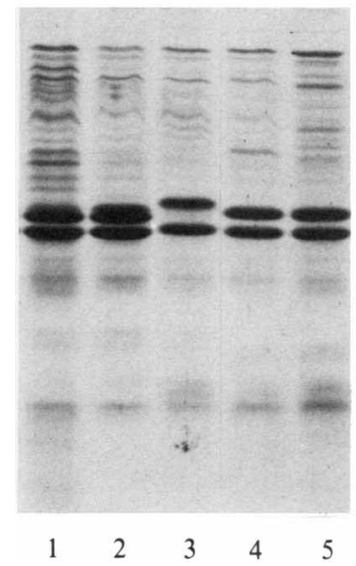

(b)

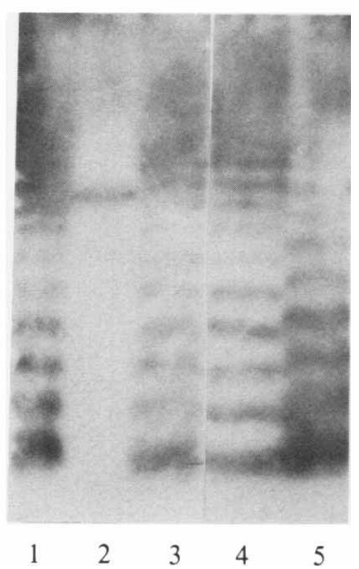

Fig. 3. (a) Polypeptide patterns of cell envelopes shown by Coomassie brilliant blue staining. (b) Immunochemical detection by GIRA of O18 lipopolysaccharide in the cell envelopes of serotype 018 strains. In each case cell envelopes were obtained from: lane 1, strain 7804011 (O18:K1); lane 2, strain $\mathrm{H} 882.79(\mathrm{O} 18: \mathrm{Kl})$; lane 3 , reference strain $\mathrm{O} 18: \mathrm{K}^{-}$; lane 4, reference strain $\mathrm{O} 18: \mathrm{K} 76$; lane 5 , strain H755-79 (O18:K76). 


\section{Cross-reactions between strains typed as 083 and 021}

Cross-reactions between O-serotypes are well known (Ørskov et al., 1977). The nature of the cross-reactions between serotype 083 and $\mathrm{O} 21$ strains was investigated. The 083 strains were agglutinated by anti-O21 serum and vice versa (Table 1). As shown in Fig. $4 b$ antiserum specific for O83-lipopolysaccharide cross-reacted with lipopolysaccharide of strain 781123 typed as $\mathrm{O} 21$ : K1. Anti-O83 serum absorbed with boiled cells of the $\mathrm{O} 21$ strain 781123 lost its reactivity both in GIRA and in agglutination towards O21-lipopolysaccharide (Fig. 4d and Table 1). Similarly, anti-O21 serum absorbed with boiled cells of strain 790163I, typed as O83, lost its reactivity towards cell envelopes of strain 790163I in GIRA (compare Fig. $4 c$ and $e$ ) and did not agglutinate $\mathrm{O} 83$ cells (Table 1). The nature of the cross-reacting antigens was different in both cases from type-specific lipopolysaccharides (compare Fig. $4 b$ and $c$ with $d$ and $e$ ) since the band patterns for $\mathrm{O} 83$ and $\mathrm{O} 21$ were different. In the case of strain 7901631 (O83:K1) the crossreacting antigen is also lipopolysaccharide, since the cross-reaction was also observed with isolated lipopolysaccharide. The cross-reacting antibodies in anti-O21 serum reacted with polysaccharide-like antigens, which migrate in the top part of the gel (Poolman et al., 1978).

Table 1. Cross-reactions between 021 and 083 antisera measured by micro-agglutination

\begin{tabular}{|c|c|c|c|c|}
\hline \multirow{3}{*}{$\begin{array}{c}\text { Agglutinating } \\
\text { strain }\end{array}$} & \multicolumn{4}{|c|}{ Agglutination titre with: } \\
\hline & \multicolumn{2}{|c|}{ Anti-O21 serum* } & \multicolumn{2}{|c|}{ Anti-083 serum $†$} \\
\hline & Unabsorbed & Absorbed & Unabsorbed & Absorbed \\
\hline O21 st & $\geqslant 10000$ & $\geqslant 10000$ & 5000 & - \\
\hline $781123(\mathrm{O} 21: \mathrm{K} 1)$ & $\geqslant 10000$ & $\geqslant 10000$ & 2560 & - \\
\hline $\mathrm{O} 21: \mathrm{K} 20 \mathrm{st}$ & $\geqslant 10000$ & ND & 5000 & 一 \\
\hline $790163 \mathrm{I}(\mathrm{O} 83: \mathrm{K} 1)$ & $\geqslant 10000$ & 80 & 5000 & 5000 \\
\hline H1137-79 (O83:K1) & $\geqslant 10000$ & 160 & 10000 & 10000 \\
\hline H908-78 (O83:K1) & $\geqslant 10000$ & ND & 10000 & 5000 \\
\hline $\mathrm{O} 4: \mathrm{K} 3$ & - & - & - & - \\
\hline
\end{tabular}

ND, Not determined; -, no agglutination.

* Antiserum found to be specific by SGIP was used as 'unabsorbed' serum. This was further absorbed with boiled cells of strain $790163 \mathrm{I}(\mathrm{O} 83: \mathrm{K} 1)$.

$\dagger$ Antiserum found to be specific by SGIP (cf. Fig. 1) was absorbed with boiled cells of strain 781123 (O21:K1) ('absorbed').

(a)

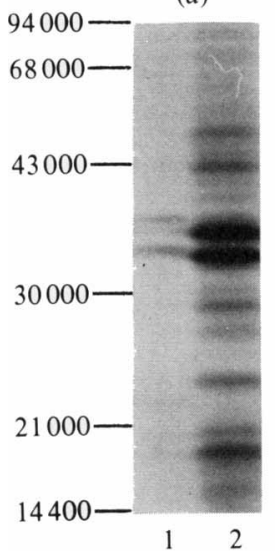

(b)

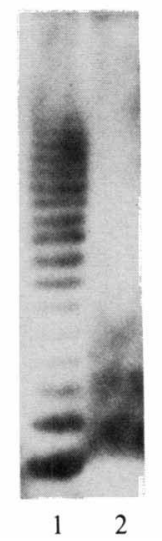

(c)

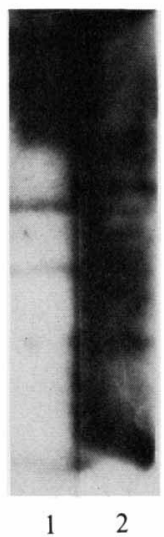

(d)

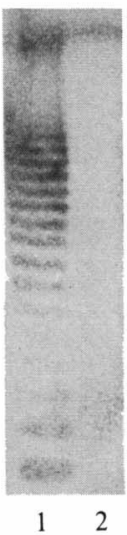

$(e)$

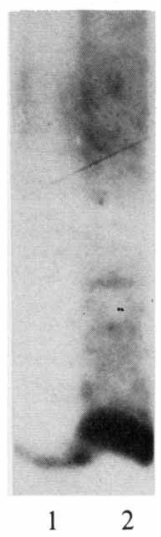

Fig. 4. Cross-reactions observed with anti-O83 and anti-O21 sera. In each case lane 1 contains cell envelopes of strain $790163 \mathrm{I}(\mathrm{O} 83: \mathrm{K} 1)$ and lane 2 those of strain 781123 (O21:K1). (a) Polypeptide pattern shown by Coomassie brilliant blue staining. $(b-e)$ Immunochemical profile, after incubation with the following typing sera : $(b)$ anti-O83, (c) anti-O21, $(d)$ anti-O83 absorbed with $\mathrm{O} 21$ cells, $(e)$ anti$\mathrm{O} 21$ absorbed with $\mathrm{O} 83$ cells. The positions of molecular weight marker bands are indicated. 


\section{DISCUSSION}

Lipopolysaccharides from several invasive $E$. coli strains, which contain O-antigenic side chains appeared heterogeneous, since multiple bands could be visualized in gels after reaction with specific antisera (Figs 1 and 2). Each serotype had a type-specific band pattern. These band patterns resemble the multiple band patterns observed for E. coli O111, Salmonella typhimurium LT2 and Chromatium vinosum lipopolysaccharides, for which it was shown that these bands represent lipopolysaccharide molecules with different degrees of polymerization of the Oantigen subunits (Goldman \& Leive, 1980; Palva \& Mäkelä, 1980; Hurlbert \& Hurlbert, 1977). This heterogeneity is probably caused by coupling of $\mathrm{O}$-antigen polysaccharide precursors (with a heterogeneous length distribution) to the core-lipid A region of lipopolysaccharide during its synthesis (Robbins \& Wright, 1971; Palva \& Mäkelä, 1980). In addition, post-translocational modification of the side chains, which sometimes results in form variation (Yuasa et al., 1969), might contribute to the heterogeneity of lipopolysaccharide. Finally, heterogeneity of the corelipid A part of lipopolysaccharide has been described for E. coli and S. typhimurium (Alphen $e t$ al., 1980, Mühlradt et al., 1977) with respect to the amount of phosphate and substituents, which might influence the charge and thereby the electrophoretic mobility of the molecule. The slight differences in band patterns observed in various strains serotyped as $\mathbf{O} 18 \mathrm{might}$ be explained by the latter kind of heterogeneity (Fig. 3). It is very unlikely that the band patterns resulted from various degrees of aggregation of one defined lipopolysaccharide molecule since (1) in the case of $E$. coli $\mathrm{O} 111$ the amount of $\mathrm{O}$-antigenic subunit sugars increases relative to the amount of lipid A phosphate with increasing molecular weight of the bands (Goldman \& Leive, 1980), (2) the band patterns were similar in cell envelopes, cells and isolated lipopolysaccharides and did not depend on boiling in SDS (results not shown).

Not all the lipopolysaccharide molecules of strains with O18-serotypes appeared as band patterns with type-specific antiserum in GIRA or SGIP analyses (Fig. 3). In some strains only specific immunodeterminants were present on polysaccharide-like components which hardly entered the gel (Fig. 3). This was not due to loss of the $\mathrm{O}$-antigen of the lipopolysaccharide since boiled cells of these strains strongly agglutinated in anti-O18 serum, indicating that specific determinants were present on the cells. Summarizing, in O18-serotyped strains the serotypespecific determinants are associated with various molecular structures.

Another exception to the regular banding pattern was found for O21 lipopolysaccharide (Fig. 4). The broad smear in the gel in addition to the band at the front is indicative of polysaccharide structures (Poolman \& Zanen, 1980). It might be that O21 represents a heat-stable polysaccharide not exposed on the cell surface in untreated cells or that the linkage between $\mathrm{O}$ antigen and core-lipid $\mathbf{A}$ is weak, resulting in polysaccharide and rough lipopolysaccharide. Since lipopolysaccharides can be discriminated from polysaccharides by the GIRA method (Poolman \& Zanen, 1980) it would be useful to apply this technique to the analysis of the polysaccharide or lipopolysaccharide nature of the known $\mathrm{O}$ - and $\mathrm{K}$-serotypes in $E$. coli.

The main purpose of this paper was to combine the separating capacity of SDSpolyacrylamide gels with an immunological detection of the $\mathrm{O}$-antigens in order to get a better understanding of the molecular nature of the serotypes and the specificity of the typing antisera. The GIRA method appeared to be more sensitive than the SGIP method, a fact of special importance when weak antisera are analysed. However, the SGIP technique does have the advantage that the results are obtained faster and that radiolabelling is not required.

Absorption of typing sera to remove cross-reactivity usually coincided with a two- to fourfold reduction in agglutination titre, indicating that a considerable portion (50-75\%) of the antibodies were directed against cross-reactive antigens. This may have considerable implications as regards the typing of strains which appear to agglutinate with low titres. The nature of these cross-reactions appeared complex. Antibodies against several proteins (Fig. 1) occurred next to antibodies against other lipopolysaccharides (Fig. 4b) and (possibly) polysaccharide (Fig. 4c).

We thank Dr J. T. Poolman for introducing us to the GIRA and SGIP techniques and for stimulating discussions. Drs F. and I. Ørskov and P. A. M. Guinée are gratefully acknowledged for their gifts of strains and typing antisera and for the O-serotyping of strains. 


\section{REFERENCES}

AlPhen, L. VAN, VerkleiJ, A., Burnell, E. \& LUGTENBERG, B. (1980). ${ }^{31} \mathrm{P}$ nuclear magnetic resonance and freeze fracture electron microscopy studies on Escherichia coli. II. Lipopolysaccharide and lipopolysaccharide-phospholipid complexes. Biochimica et biophysica acta 597, 502-517.

ALPHEN, L. VAN, KEMPEN-DE TROYE, F. vaN \& ZANEN, H. C. (1982). Characterization of cell envelope proteins and lipopolysaccharides of Escherichia coli isolates from patients with neonatal meningitis. FEMS Microbiology Letters (in the Press).

AlPHEN, W. van, LUGTENBERG, B. \& Berendsen, W. (1976). Heptose-deficient mutants of Escherichia coli $\mathrm{K}-12$ deficient in up to three major outer membrane proteins. Molecular and General Genetics 147, 263269.

Burnell, E., Alphen, L. van, Verkleij, A., Kruijff, B. DE \& LUGTENBERG, B. (1980). ${ }^{31} \mathrm{P}$ nuclear magnetic resonance and freeze fracture electron microscopy studies on Escherichia coli. III. The outer membrane. Biochimica et biophysica acta $\mathbf{5 9 7}$, 518-532.

Fairbanks, G., Steck, T. L. \& Wallach, D. F. H. (1971). Electrophoretic analysis of the major polypeptides of the human erythrocyte membrane. Biochemistry 10, 2606-2617.

Galanos, C., LÜDERITZ, O., RieTsChel, E. T. \& WeSTPHAL, O. (1977). Newer aspects of the chemistry and biology of bacterial lipopolysaccharides with special reference to their lipid A component. International Reviews of Biochemistry (Biochemistry of Lipids II) 14, 239-335.

Goldman, R. C. \& Leive, L. (1980). Heterogeneity of antigenic-side-chain length in lipopolysaccharide from Escherichia coli 0111 and Salmonella typhimurium LT2. European Journal of Biochemistry 107, 145-153.

Heerikhuisen, H. van, Kwak, E., Bruggen, E. F. J. VAN \& WITHOLT, B. (1975). Characterization of a low density cytoplasmic membrane subfraction from Escherichia coli. Biochimica et biophysica acta 413, 177-191.

Hurlbert, R. E. \& HurLbert, I. M. (1977). Biological and physiochemical properties of the lipopolysaccharides of Chromatium vinosum. Infection and Immunity 16, 983-994.

LiNDBERG, A. A. \& Holme, T. (1972). Evaluation of some extraction methods for the preparation of bacterial lipopolysaccharides for structural analysis. Acta pathologica et microbiologica scandinavica section B, Microbiology 80, 751-759.

Lugtenberg, B., Meijers, J., Peters, R., Hoek, P. VAN DER \& ALPHEN, L. VAN (1975). Electrophoretic resolution of the major outer membrane protein of Escherichia coli K-12 into four bands. FEBS Letters 58, 254-258

MüHlRadT, P. F. \& Golecki, J. R. (1975). Asymmetrical distribution and artifactual reorientation of lipopolysaccharide in the outer membrane bilayer of Salmonella typhimurium. European Journal of Biochemistry 51, 343-352.

Mühlradt, P. F., Wray, V. \& LehmanN, V. (1977). A ${ }^{31} \mathrm{P}$-nuclear-magnetic-resonance study of the phosphate groups in lipopolysaccharide and lipid A from Salmonella. European Journal of Biochemistry 81, 193-203.

ØRSKOV, I., ØRSKOV, F., JANN, B. \& JANN, K. (1977). Serology, chemistry and genetics of $O$ and $K$ antigens of Escherichia coli. Bacteriological Reviews 41, 667-710.

OsBORN, M. J. (1979). Biosynthesis and assembly of the lipopolysaccharide of the outer membrane. In $\mathrm{Bac}$ terial Outer Membranes, pp. 15-35. Edited by $\mathbf{M}$. Inouye. New York: Wiley.

Palva, E. T. \& MäKelä, P. H. (1980). Lipopolysaccharide heterogeneity in Salmonella typhimurium analyzed by sodium dodecyl sulfate/polyacrylamide gel electrophoresis. European Journal of Biochemistry 107, 137-143.

Poolman, J. T. \& Zanen, H. C. (1980). Detection of antibody activity in human sera against meningococcal cell wall antigens using a gel-immunoradio-assay (GIRA). FEMS Microbiology Letters 7, 293-296.

Poolman, J. T. Hopman, C. Th. P. \& Zanen, H. C. (1978). Immunochemical characterization on Neisseria meningitidis serotype antigens by immunodiffusion and SDS-polyacrylamide gel electrophoresis immunoperoxidase techniques and the distribution of serotypes among cases and carriers. Journal of General Microbiology 116, 465-473.

RobBins, P. V. \& WRIGHT, A. (1971). Biosynthesis of O-antigens. In Microbial Toxins, vol. 4, pp. 351-368. Edited by S. Weinbaum \& S. Ajl. London : Academic Press.

Segrest, J. P. \& JACKson, R. L. (1972). Molecular weight determination of glycoproteins by polyacrylamide gel electrophoresis in sodium dodecyl sylphate. Methods in Enzymology 28, 54-63.

WESTPHAL, O. \& JANN, K. (1965). Bacterial lipopolysaccharides. Extraction with phenol-water and further applications of the procedure. Methods in Carbohydrate Chemistry 5, 83-91.

Yuasa, R., Levinthal, M. \& Nikaido, H. (1969). Biosynthesis of cell wall lipopolysaccharide in mutants of Salmonella. Journal of Bacteriology 100, 433-444. 